\title{
Historical colonization and demography of the Mediterranean damselfish, Chromis chromis
}

\author{
VERA S. DOMINGUES,${ }^{*}+\S$ GIUSEPPE BUCCIARELLI,+†VITOR C. ALMADA* and \\ GIACOMO BERNARDI† \\ *Instituto Superior de Psicologia Aplicada, Unidade de Investigação em Eco-Etologia, R. Jardim do Tabaco 34, 1149-041 Lisboa, \\ Portugal, +Department of Ecology and Evolutionary Biology, University of California Santa Cruz, 100 Shaffer Road, Santa Cruz, \\ 95060, California, USA, †Stazione Zoologica Anton Dohrn, Villa Comunale, Naples, Italy, §IMAR/DOP, Universidade dos Açores, \\ Cais de Santa Cruz-9901-862 Horta, Açores, Portugal
}

\begin{abstract}
The desiccation of the Mediterranean Sea during the Messinian Salinity Crisis 6.0-5.3 million years ago (Ma), caused a major extinction of the marine ichthyofauna of the Mediterranean. This was followed by an abrupt replenishment of the Mediterranean from the Atlantic after the opening of the Strait of Gibraltar. In this study, we combined demographic and phylogeographic approaches using mitochondrial and nuclear DNA markers to test the alternative hypotheses of where (Atlantic or Mediterranean) and when (before or after the Messinian Salinity Crisis) speciation occurred in the Mediterranean damselfish, Chromis chromis. The closely related geminate transisthmian pair Chromis multilineata and Chromis atrilobata was used as a way of obtaining an internally calibrated molecular clock. We estimated $C$. chromis speciation timing both by determining the time of divergence between $C$. chromis and its Atlantic sister species Chromis limbata (0.93-3.26 Ma depending on the molecular marker used, e.g. 1.23-1.39 Ma for the control region), and by determining the time of coalescence for $C$. chromis based on mitochondrial control region sequences (0.14-0.21 Ma). The time of speciation of $C$. chromis was always posterior to the replenishment of the Mediterranean basin, after the Messinian Salinity Crisis. Within the Mediterranean, C. chromis population structure and demographic characteristics revealed a genetic break at the Peloponnese, Greece, with directional and eastbound gene flow between western and eastern groups. The eastern group was found to be more recent and with a faster growing population (coalescent time $=0.09-0.13 \mathrm{Ma}$, growth $=485.3$ ) than the western group (coalescent time $=0.13-0.20 \mathrm{Ma}$, growth $=325.6$. Our data thus suggested a western origin of $C$. chromis, most likely within the Mediterranean. Low sea water levels during the glacial periods, the hydrographic regime of the Mediterranean and dispersal restriction during the short pelagic larval phase of $C$. chromis (18-19 days) have probably played an important role in C. chromis historical colonization.
\end{abstract}

Keywords: Chromis, coalescence, Mediterranean, Messinian Salinity Crisis, phylogeography, speciation

Received 16 May 2005; revision accepted 25 July 2005

\section{Introduction}

The Mediterranean Sea underwent at least one episode of desiccation and replenishment, the so-called Messinian Salinity Crisis (MSC) that occurred between 6.0 and 5.3 million years ago (Ma) (Hsü et al. 1977; Krijgsman et al.

Correspondence: Vera S. Domingues, Fax: +351 218860954; E-mail: veradomingues@ispa.pt
1999; Duggen et al. 2003). Except for a small number of species capable of surviving in brackish or hypersaline lagoons, the marine ichthyofauna of the Mediterranean became extinct during this desiccation episode. After that period, the Mediterranean abruptly refilled from the Atlantic following the opening of the Strait of Gibraltar. At present, the Mediterranean Sea is defined as a warm-temperate sea and harbours about 540 species of fish. Briggs (1974) estimated that approximately 52 species $(9.6 \%)$ are endemics. 
Subsequent studies, however, showed that some of the so-called endemics are also found in the Atlantic areas adjacent to the entrance of the Mediterranean (Almada et al. 2001). Few species are shared with the Indian Ocean; these are recent Lessepsian migrants invading from the Red Sea through the Suez Canal (approximately 60 species, Golani 1999). The vast majority of the Mediterranean marine fish species originated from the adjacent Atlantic fish fauna by invading via the Strait of Gibraltar (e.g. Bargelloni et al. 2003). Mediterranean endemics are either the result of in situ speciation (occurring after the MSC), or experienced an extinction of their Atlantic populations after colonizing the Mediterranean. In addition, since the Mediterranean waters remained warmer that those of the adjacent Atlantic during glacial peeks (Thiede 1978), many species now present in the warm temperate Atlantic, likely survived the cold phases of the glacial cycles within the Mediterranean, recolonizing the Atlantic when more favourable temperatures were re-established during interglacial phases like the present one (Almada et al. 2001). Thus, species of Mediterranean fishes provide a unique opportunity to understand the processes of colonization, evolution, and local adaptation.

In this study, we have focused on the Mediterranean damselfish, Chromis chromis (Pomacentridae). The species is broadly distributed in the Mediterranean over rocky reefs and seagrass beds, usually in waters shallower than 25 m (Lythgoe \& Lythgoe 1971; Riedl 1983). Besides its Mediterranean distribution, some individuals are observed outside the Strait of Gibraltar, along the Atlantic coast of Portugal (Wood 1977; personal observation).

The genus Chromis comprises 75 species that are distributed worldwide (Allen 1991; Tang 2001; Quenouille et al. 2004). C. chromis is found in the Mediterranean and the Atlantic areas adjacent to this sea. Chromis limbata, the most likely sister species of C. chromis (Wood 1977; L. Rocha et al., unpublished), is restricted to the Macaronesian islands (Azores, Madeira, and Canaries) and the western coast of North Africa (between Senegal and Congo, Wood 1977; L. Rocha et al., unpublished). Eastern and central Atlantic Chromis species also include Chromis lubbocki (Cape Verde Islands), Chromis sanctahelena (Saint Helena Island), Chromis cadenati (Senegal to Ghana), and Chromis multilineata (from western Africa to the western Atlantic) (Allen 1991). This latter species is considered a transisthmian geminate, which diverged from its eastern Pacific sister species Chromis atrilobata, at the rise of the Isthmus of Panama, 3.1-3.5 million years ago (Ma) (L. Rocha et al., unpublished).

Several genetic studies have focused on the phylogeographic relationships of marine organisms both between the Atlantic and the Mediterranean Sea and within the Mediterranean. Some studies have shown a strong genetic divergence between Atlantic and Mediterranean faunas, due to the isolation of both seas during the Pleistocene glaciations and to the present-day hydrographic barriers, while others found very high levels of gene flow between these two regions. For instance, Bargelloni et al. (2003) found strong to no differentiation between the Atlantic and the Mediterranean for five teleosts species of the family Sparidae. The wrasse (Thalassoma pavo) (Costagliola et al. 2004), and the chub mackerel (Scomber japonicus, Zardoya et al. 2004) were described as having high gene flow levels between the Atlantic and the Mediterranean. Stamatis et al. (2004) found no signs of an Atlantic-Mediterranean divide for the Norway lobster (Nephrops norvegicus). In contrast, Pannacciulli et al. (1997) found marked genetic differentiation between Atlantic and Mediterranean populations in two species of Chthamalus barnacles, with the Almeria-Oran front (Fig. 1) preventing extended gene flow between these two regions. Pérez-Losada et al. $(1999,2002)$ described genetic differentiation between Atlantic and Mediterranean populations of the cuttlefish Sepia officinalis, and so did Quesada et al. (1995) for the mussel Mytilus galloprovincialis. Narciri et al. (1999) described two groups of populations of the sea bass Dicentrarchus labrax and postulated that the divide may correspond to the Almeria-Oran oceanographic front. Comparing nuclear and cytoplasmic markers for the same species, Lemaire et al. (2005) suggested the existence of a hybrid zone in the Alborean Sea.

Similarly, within the Mediterranean Sea, studies showed high levels of gene flow, or alternatively strong population differences. Kotoulas et al. (1995) and Pujolar et al. (2002) found no genetic structure within the Atlantic for the swordfish Xiphias gladius. The two populations east of the discontinuity found between the Atlantic and the Mediterranean for the mussel $M$. galloprovincialis analysed by Quesada et al. (1995) were homogenous in haplotype frequency. In contrast, some studies evidenced population structure within the Mediterranean with genetic breaks observed at different places. Indeed, some studies evidenced a restriction of gene flow at the 'saddle' between Sicily and Tunisia (Fig. 1) (e.g. the goby Pomatoschistus minutus, Stefanni \& Thorley 2003, and the mackerel S. japonicus, Zardoya et al. 2004), while others found a strong break in Greece just south of the Peloponnese (Fig. 1) (e.g. the anchovy Engraulis encrasicolus, Magoulas et al. 1996; the sea bass Dicentrarchus labrax, Bahri-Sfar et al. 2000; the bivalve Cerastoderma glaucum, Nikula \& Väinölä 2003; and the wrasse T. pavo, Costagliola et al. 2004). Borsa et al. (1997) identified three geographically isolated populations of the flounders Platichthys in the Mediterranean, separated by the two breaks mentioned above. The Mediterranean damselfish may conform to scenarios described for other species, with the two extreme situations being strong population structure between the Atlantic and the Mediterranean and within the Mediterranean, or high gene flow and no population structure.

Dispersal and vicariance have both probably played an important role in shaping the different phylogeographic 


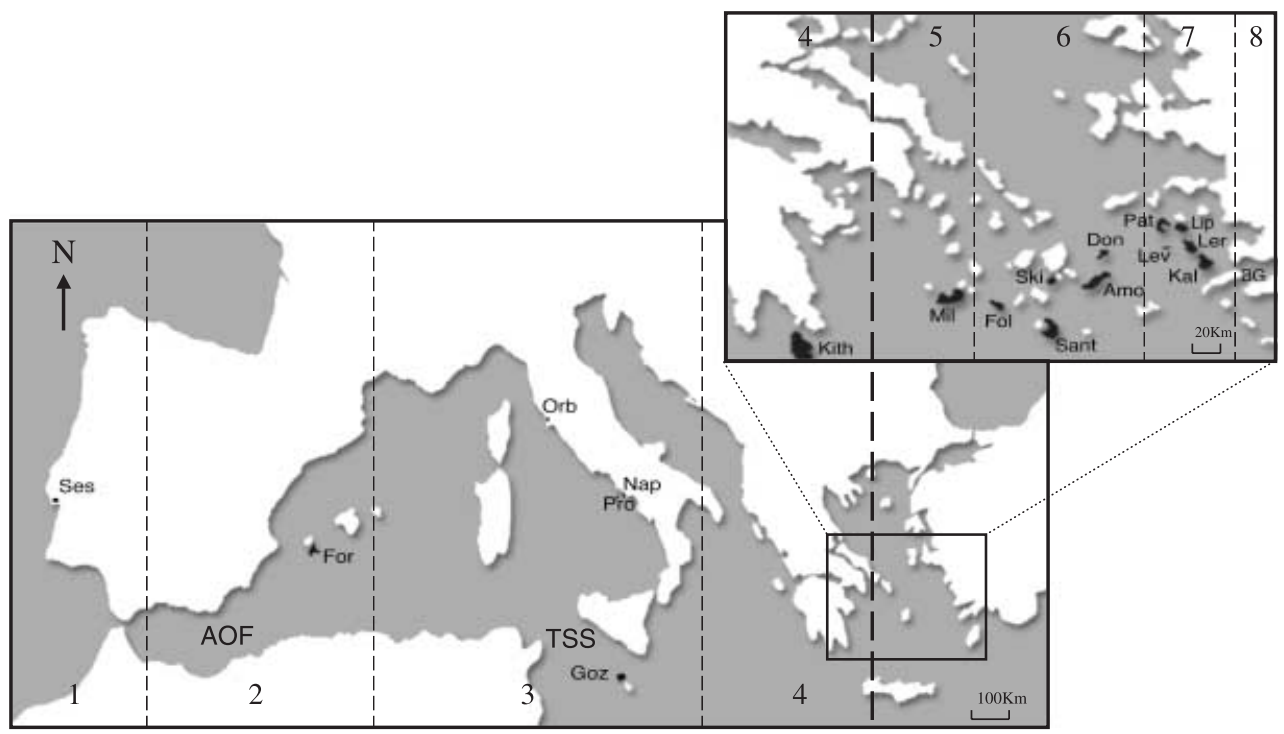

Fig. 1 Chromis chromis sampling locations in the Atlantic and the Mediterranean. Samples were collected in the following localities: Sesimbra (Ses), Portugal; Formentera (For), Spain; Orbetello (Orb), Naples (Nap) and Procida (Pro), Italy; Gozo (Goz), Malta; Kithira (Kit), Milos (Mil), Folegandros (Fol), Santorini (Sant), Skinousa (Ski), Amorgos (Amo), Donoussa (Don), Levitha (Lev), Patmos (Pat), Lipsos (Lip), Leros (Ler), Kalimnos (Kal), Greece; and Bodrum Gulf (BG),Turkey. Dashed lines limit regions (nos 1-8) used for testing degrees of differentiation for multiple groupings. The Tunisia-Sicily saddle is indicated by 'TSS', and the Almeria-Oran front is indicated by 'AOF'.

patterns mentioned above. Low sea water levels and changes in ocean circulation patterns during the glacial periods could have played an important role in the segregation of populations in the Mediterranean. Dispersal restriction during the pelagic larval phase has probably contributed to the current situation. In the case of $C$. chromis, after a relatively short pelagic larval duration (18-19 days, Raventós \& Macpherson 2001), fishes tend to be sedentary over seagrass or rocky reefs at depths ranging from 3 to $35 \mathrm{~m}$, where they live for a maximum of 9 years (Dulcic \& Kraljevic 1995). They reproduce repeatedly throughout the spawning season (June-September) (Picciulin et al. 2004). Males establish territories, prepare nests and court females. Females lay demersal eggs that are guarded by males until hatching. As for other pomacentrids, C. chromis has been reported to exhibit reproductive parasitism (Picciulin et al. 2004). In this study, our goal was to test the alternative hypotheses related to speciation in Mediterranean fishes, and specifically of where and when speciation occurred in the Mediterranean damselfish, C. chromis. If it speciated within the Mediterranean, we would predict the divergence from its sister species, C. limbata, as well as the coalescence time of C. chromis, to have occurred after the MSC. In contrast, if $C$. chromis colonized the Mediterranean from the Atlantic, the split between C. chromis and C. limbata could have pre-dated the MSC, resulting in a divergence time from C. limbata, and coalescence of $C$. chromis, to preceed the formation of the present-day Mediterranean Sea. In addition, we may also find a signature of recent expansion in C. chromis populations, possibly showing a migration trend and expansion going eastward inside the Mediterranean. A third possibility is for an Atlantic origin of C. chromis and the split between C. chromis and C. limbata to have occurred after the MSC. This hypothesis, however, requires both a rapid colonization of the Mediterranean and an extinction of Atlantic populations of C. chromis over a relatively short time.

In order to determine if speciation occurred recently within the Mediterranean Sea, or if it occurred in the Atlantic, with a subsequent colonization event, we investigated the following questions: (i) Can a phylogeographic approach coupled with historical demographic parameters estimate speciation time in C. chromis in relation to the MSC? (ii) Are population structure and migration patterns within the Mediterranean bearing signatures of recent colonization and expansion?

To answer our questions, we decided to combine a phylogeographic approach using mitochondrial and nuclear markers, with a demographic study of the species. We used C. chromis as our focal species, C. limbata as its sister species, and also the geminate transisthmian pair C. multilineata and C. atrilobata as a way to calibrate the molecular clock and estimate the mutation rate for this closely related group of species.

\section{Materials and methods}

\section{Sampling and DNA extraction}

Sampling localities, dates of collections and number of individuals are given in Table 1 and Fig. 1. Samples of 
Table 1 Collection localities of Chromis chromis, Chromis limbata and outgroup species, Chromis multilineata and Chromis atrilobata, used in the present study. Number of individuals, number of haplotypes ( $\mathrm{Hn}$ ) and Haplotype diversity (Hd) (for mitochondrial control region) were calculated using DNASP (Rozas et al. 2003). Numbers after C. chromis localities represent regions described in Fig. 1. Locality labels from Figs 1 and 2, and Fig. 3 are between parentheses

\begin{tabular}{|c|c|c|c|c|c|}
\hline Species & Locality & No. of individuals & $\mathrm{Hn}$ & $\mathrm{Hd}$ & Collection date \\
\hline \multicolumn{6}{|l|}{ C. chromis $(\mathrm{CCH})$} \\
\hline Portugal & 1 Sesimbra (Ses) & 14 & 14 & 1 & November 2004 \\
\hline Spain & 2 Formentera (For) & 22 & 20 & 0.991 & October 2003 \\
\hline \multirow[t]{2}{*}{ Italy } & 3 Orbetello (Orb) & 10 & 10 & 1 & June 1996 \\
\hline & "Naples/Procida (Nap/Pro) & 13 & 10 & 0.949 & June 2001/July 2003 \\
\hline Malta & " Gozo (Goz) & 6 & 6 & 1 & April 2003 \\
\hline \multirow[t]{12}{*}{ Greece } & 4 Kithira (Kit) & 7 & 6 & 0.952 & May 2003 \\
\hline & 5 Milos (Mil) & 7 & 6 & 0.952 & May 2003 \\
\hline & "Folegandros (Fol) & 8 & 8 & 1 & June 2003 \\
\hline & "Santorini (Sant) & 7 & 6 & 0.952 & June 2003 \\
\hline & "Skinousa (Ski) & 10 & 8 & 0.933 & June 2003 \\
\hline & "Amorgos (Amo) & 6 & 5 & 0.933 & July 2003 \\
\hline & "Donoussa (Don) & 10 & 10 & 1 & August 2003 \\
\hline & 6 Levitha (Lev) & 9 & 7 & 0.944 & August 2003 \\
\hline & "Patmos (Pat) & 9 & 6 & 0.889 & September 2003 \\
\hline & "Lipsos (Lip) & 8 & 7 & 0.964 & August 2003 \\
\hline & "Leros (Ler) & 9 & 8 & 0.792 & September 2003 \\
\hline & "Kalimnos (Kal) & 9 & 9 & 1 & July 2003 \\
\hline Turkey & 7 Bodrum Gulf (BG) & 21 & 17 & 0.976 & October 2003 \\
\hline $\begin{array}{l}\text { Total for C. chromis } \\
\text { C. limbata (CLI) }\end{array}$ & & 185 & 116 & 0.625 & \\
\hline \multirow[t]{2}{*}{ Portugal } & Azores (Az) & 4 & & & December 2003 \\
\hline & Madeira (Mad) & 4 & & & September 2003 \\
\hline Spain & Canaries (Can) & 4 & & & February 2004 \\
\hline \multicolumn{6}{|l|}{ C. multilineata (CMU) } \\
\hline Panama & San Blas (Atlantic coast) (Pan) & 2 & & & March 1997 \\
\hline \multicolumn{6}{|l|}{ C. atrilobata (CAT) } \\
\hline Mexico & B. Tortugas (Pacific coast) (Mex) & 1 & & & October 1999 \\
\hline \multirow[t]{3}{*}{ Galapagos } & Santa Cruz (SC) & 2 & & & December 1999 \\
\hline & Española (Esp) & 2 & & & January 2000 \\
\hline & Floreana (Flo) & 1 & & & January 2000 \\
\hline
\end{tabular}

Chromis chromis were obtained from one location in the Atlantic and 18 locations in the Mediterranean corresponding to 17 populations (Naples and Procida locations were treated as a single population due to their proximity). Six of the Mediterranean locations were in the western basin, the remaining 12 were in the eastern basin. Chromis limbata (C. chromis sister species) was collected from three Atlantic islands (Azores, Madeira, and the Canaries). We used Chromis multilineata and Chromis atrilobata as outgroups. Samples were collected by spear or hand nets while scuba diving. Fin clips were cut immediately after collection of the individuals and stored at ambient temperature in 95\% ethanol. Tissues were digested overnight at $55^{\circ} \mathrm{C}$ in $700 \mu \mathrm{L}$ of extraction buffer ( $400 \mathrm{~mm} \mathrm{NaCl}, 10 \mathrm{~mm}$ Tris, $2 \mathrm{~mm}$ EDTA, $1 \%$ SDS). We purified the DNA by standard chloroform extraction and isopropanol precipitation (Sambrook et al. 1989).

\section{Polymerase chain reaction and DNA sequencing}

Amplification of the $5^{\prime}$ hypervariable portion of the mitochondrial control region (also called D-loop) was accomplished with universal primers CR-A and CR-E (Lee et al. 1995), and used a cycling profile of $45 \mathrm{~s}$ at $94{ }^{\circ} \mathrm{C}, 45 \mathrm{~s}$ at $52{ }^{\circ} \mathrm{C}, 1 \mathrm{~min}$ at $72{ }^{\circ} \mathrm{C}$, for 35 cycles. In addition, we amplified and sequenced segments of the mitochondrial 16S rRNA and cytochrome $b$ genes as well as the nuclear 1st intron of the alpha-tropomyosin (TROP) for a randomly chosen subset of our samples. Cytochrome $b$ and $16 \mathrm{~S}$ rRNA were amplified for $45 \mathrm{~s}$ at $94{ }^{\circ} \mathrm{C}, 45 \mathrm{~s}$ at $48^{\circ} \mathrm{C}$, and $1 \mathrm{~min}$ at $72{ }^{\circ} \mathrm{C}$ for 35 cycles, with the following primers: GLUDG-L and CB3H, and 16SAR and 16SBR (Kocher et al. 1989). Tropomyosin intron was amplified for $30 \mathrm{~s}$ at $94{ }^{\circ} \mathrm{C}, 1 \mathrm{~min}$ at $60{ }^{\circ} \mathrm{C}$, and $2 \mathrm{~min}$ at $72{ }^{\circ} \mathrm{C}$ for 35 cycles with the following primers: TR1F and TR1R (Hassan et al. 2002). Each 13- $\mu \mathrm{L}$ 


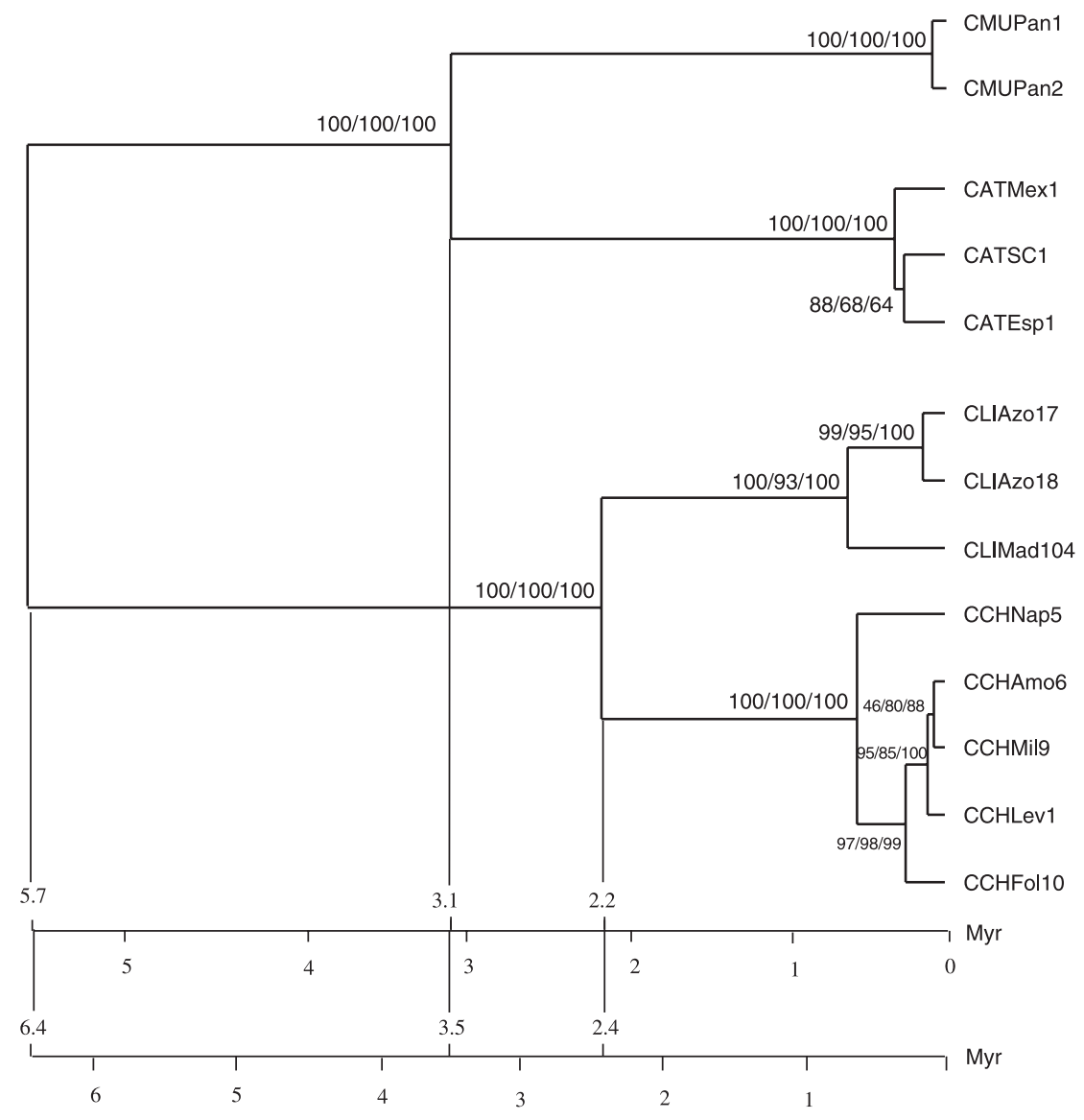

Fig. 2 Phylogenetic relationship between Chromis chromis and Chromis limbata, with Chromis multilineata and Chromis atrilobata used as outgroups. Phylogenetic reconstruction was based on the combined mitochondrial control region, 16S rRNA, cytochrome $b$ and the nuclear 1st intron of the tropomyosin gene sequences using a maximum-likelihood method, with HKY + G model and an enforced molecular clock. Alternative reconstruction methods, neighbour-joining, maximum parsimony and maximum likelihood (with or without enforcing a molecular clock) resulted in the same topology. Labels are described in Table 1. The length of each branch is proportional to the number of nucleotide substitutions. Bootstrap values for each node are shown as percentages for neighbour-joining, parsimony and likelihood methods, respectively. Timescales presented at the bottom of the figure are based on the split of Chromis atrilobata and Chromis multilineata coinciding with the rise of the Isthmus of Panama (3.1-3.5 Ma). reaction contained 5-50 ng of DNA, $10 \mathrm{~mm}$ Tris- $\mathrm{HCl}$ ( $\mathrm{pH}$ 8.3), $50 \mathrm{~mm} \mathrm{KCl}, 1.5 \mathrm{~mm} \mathrm{MgCl}_{2}, 1.25 \mathrm{U}$ of Taq DNA polymerase (PerkinElmer), $150 \mathrm{~mm}$ of each dNTP, and $0.3 \mathrm{~mm}$ of each primer. After purification following the manufacturer's protocol (Applied Biosystems), direct sequencing was performed with an ABI 3100 automated sequencer (Applied Biosystems). Sequencing was performed in one direction only for the mitochondrial control region, cyt $b$ and 16S. The tropomyosin intron was sequenced in both directions. None of the sequences contained ambiguous heterozygous positions, but for two that contained a single heterozygous ( $A$ and $\mathrm{G}$ ) position that was encoded as $\mathrm{R}$ (for purines). When removing that position from the analysis, results remained unchanged, thus the position was kept for the final analysis.

\section{Data analysis}

DNA sequences and phylogenetic analyses. We used the computer program CLUSTAL v implemented by Sequence Navigator (Applied Biosystems) to align the sequences. Number of haplotypes and haplotype diversity were calculated using the software package DNASP (Rozas et al. 2003). Phylogenetic relationships based on mitochondrial control region, 16S, cyt $b$ and TROP sequences were assessed using representative individuals from each species (described in Fig. 2). Character congruence between the four fragments was tested using the incongruence-length difference test (ILD) (Farris et al. 1995) available in PAUP (version 4.0; Swofford 1998). We used three methods of phylogenetic inference: maximum parsimony (using heuristic search, TBR branch swapping, random addition of taxa and no weighting), neighbour joining and maximum likelihood, with the substitution model established using MODELTEST 3.06 (Posada \& Crandall 1998) under hLRT (HKY + G, ti / tv ratio $=2.5511$, gamma value $=0.1573$, base frequencies $\mathrm{A}=0.2786, \mathrm{C}=0.1957, \mathrm{~T}=0.2564$ and $\mathrm{G}=0.2693$ ). All methods were implemented by the software package PAUP (Swofford 1998). Additionally, we inferred phylogenetic relationships of all C. chromis specimens based on mitochondrial control region sequences using maximum-parsimony and neighbour-joining methods (with the substitution model obtained using MODELTEST under hLRT: HKY + G, ti $/$ tv ratio $=2.1676$, gamma value $=0.4752$, base frequencies $\mathrm{A}=$ $0.3676, C=0.1871, T=0.1405$ and $\mathrm{G}=0.3048$ ). Topological confidence was evaluated for all phylogenetic analyses, with 1000 bootstrap replicates (Felsenstein 1985). For maximum parsimony, bootstrap was performed using the fast-step 
method (only one tree kept at each replicate). Alternative topologies were tested using the Shimodaira-Hasegawa test (Shimodaira \& Hasegawa 1999) implemented in PAUP (Swofford 1998).

Genetic divergence and molecular clock calibration. Genetic divergence between sister species (C. chromis /C. limbata and C. multilineata/C. atrilobata) was estimated for mitochondrial control region, cyt $b, 16 \mathrm{~S}$ and TROP, using substitution models obtained with MODELTEST. In order to account for polymorphism in each species, divergence was estimated as the average pairwise distance between species minus the average pairwise distance within species. In order to test for homogeneity of rates of molecular evolution for D-loop, cyt b, 16S and TROP, we compared maximumlikelihood topologies with or without enforcing a molecular clock, using a likelihood-ratio test (Shimodaira-Hasegawa test; Shimodaira \& Hasegawa 1999), implemented by the software package PAup (Swofford 1998).

The rate of divergence between C. multilineata and C. atrilobata was calibrated using the timing of the rise of the Isthmus of Panama (3.1-3.5 Ma; Coates \& Obando 1996) as the minimum time of divergence between these two species. This molecular clock was used to estimate the minimum divergence time between C. chromis and C. limbata.

Population structure. Gene flow $\left(F_{\mathrm{ST}}\right.$ and $\mathrm{Nm}$ ) was estimated using ARLEQUIN (version 2.000; Schneider et al. 2000). Population structure was estimated by an analysis of molecular variance (AMOvA; Excoffier et al. 1997) using ARLEQUIN. Populations were grouped in different regions and alternative groupings were tested with an AMOvA to find the best fit for our data, which defined western and eastern regions of the Mediterranean. Corrections for simultaneous multiple comparisons were applied using sequential Bonferroni correction (Rice 1989).

To test for isolation by distance (IBD) we applied the Mantel test (Mantel 1967) to two matrices, $F_{\mathrm{ST}}$ values and log geographical distances in kilometres between localities. We used IBD 1.4 (Bohonak 2002) to perform the Mantel test, using 1000 replicates to test significance.

\section{Historical demography}

Chromis chromis sample locations were divided in western and eastern regions according to the results of the AMOvA. The historical demography of the western and eastern groups was first examined using mismatch distributions analysis and Tajima's $D$ test of neutrality (Tajima 1989), in order to evaluate possible events of population expansion and decline. Theoretical studies have shown that populations in long stable demographic equilibrium show a chaotic mismatch distribution, while recent rapid population expansions or bottlenecks are reflected in a unimodal mismatch distribution (Rogers \& Harpending 1992; Rogers 1995). Tajima's $D$ test is classically used to test neutrality, but it can also be used to test population growth as a population that has been experiencing expansion may result in a reject of the null hypothesis of neutrality (significant negative $D$ values).

Estimates of $\Theta(=2 N \mu$, where $\mu$ is the mutation rate for mitochondrial control region), were made for each region as well as $C$. chromis as a whole. The parameter $\Theta$ was estimated under two conditions: an unconstrained exponential growth parameter, and an assumption of constant $N$ $(\mathrm{g}=0)$. We used FLUCTUATE (Kuhner et al. 1998) to estimate the maximum likelihood of the parameters $\Theta$ and $g$ (the exponential growth parameter in units $\mu^{-1}$ ). Seeds for all analyses were generated randomly and the default transition to transversion ratio was used. Analyses were repeated 10 times per region to ensure stability of parameters estimates. Final analyses of each data set employed 10 short Monte Carlo chains of 200 steps each and 5 long chains of length 20 000, with a sample increment of 20. Exchanges and range expansions (immigration) between western and eastern regions were estimated using MIGRATE version 2.0 (Beerli \& Felsenstein 2001; Beerli 2004). Again, analyses were repeated 10 times, to ensure stability of parameter estimates. Final analyses of each data set employed 10 short Monte Carlo chains with 500 recorded genealogies and five long chains with 5000 recorded genealogies, and a sample increment of 20. A chi-squared goodness-of-fit test was performed to test the null hypothesis that migration in both directions had equal rates. The time of coalescence was estimated by assuming that coalescence was reached when the population size was reduced to $1 \%$ of its presentday value, following Wares \& Cunningham (2001). In order to estimate coalescence time, we estimated the mutation rate $(\mu)$ as $\mu=$ substitutions per site per generation. Generation time, a value necessary to estimate coalescence time, was estimated at 3 years, the approximate time for sexual maturity for C. chromis and C. limbata (Mapstone \& Wood 1975; Dulcic \& Kraljevic 1995).

\section{Results}

\section{DNA sequences and phylogenetic analyses}

The 16S rRNA and cytochrome $b$ sequences were obtained for 13 samples, 5 Chromis chromis, 3 Chromis limbata, 3 Chromis atrilobata, and 2 Chromis multilineata. Sequences for these two genes were 539 and 616 bp long, respectively. Nuclear sequences for the 1st intron of the alpha-tropomyosin gene $(347 \mathrm{bp})$ were obtained for 30 individuals, $15 \mathrm{C}$. chromis, 7 C. limbata, 6 C. atrilobata, and 2 C. multilineata. No indels were found in this intron. The null hypothesis of congruence between all four loci (D-loop, cyt $b, 16 \mathrm{~S}$ and TROP) was not rejected $(P=1)$, thus data for all loci were combined. All methods of phylogenetic inference resulted 
Table 2 Divergence of sister species Chromis atrilobata and Chromis multilineata based on mitochondrial and nuclear genes (column 1). Model of substitution for each marker obtained using MODELTEsT 3.06 (Posada \& Crandall 1998) (column 2). Sequence divergence (using substitution model obtained in MODELTEST) and rate of sequence divergence [per million years (Myr)] for Chromis atrilobata and Chromis multilineata are given in columns 3 and 4 . Rate of divergence between C. multilineata and C. atrilobata was calibrated by the rise of the Isthmus of Panama [3.1-3.5 million years ago (Ma)]. This molecular clock was used to estimate divergence time between Chromis chromis and Chromis limbata (column 6), based on their sequence divergence (column 5)

\begin{tabular}{|c|c|c|c|c|c|}
\hline & \multirow[b]{2}{*}{ Model } & \multicolumn{2}{|c|}{ C. atrilobata/C. multilineata } & \multicolumn{2}{|c|}{ C. chromis/C. limbata } \\
\hline & & $\%$ divergence & $\%$ divergence $/ \mathrm{Myr}$ & $\%$ divergence & Divergence time (Ma) \\
\hline D-loop & $\mathrm{HKY}+\mathrm{G}$ & 48.53 & $6.93-7.83$ & 19.2 & $1.23-1.39$ \\
\hline cyt $b$ & $\mathrm{HKY}+\mathrm{G}$ & 16.53 & $2.36-2.67$ & 5.79 & $1.09-1.22$ \\
\hline $16 S$ & K80 & 1.29 & $0.18-0.21$ & 1.20 & $2.89-3.26$ \\
\hline Tropomyosin & $\mathrm{JC}$ & 4.66 & $0.67-0.75$ & 1.40 & $0.93-1.05$ \\
\hline
\end{tabular}

in the same topology. A maximum-likelihood phylogeny, with an enforced molecular clock, is presented in Fig. 2. As expected, individuals from nominal species (C. chromis, C. limbata, C. multilineata and C. atrilobata) grouped in wellsupported clades, with C. chromis being the sister species of C. limbata, and C. multilineata grouping with C. atrilobata (Fig. 2).

Mitochondrial control region sequences were obtained from 205 individuals including 185 C. chromis, 12 C. limbata, 6 C. atrilobata, and 2 C. multilineata. Number of haplotypes and haplotype diversity are shown in Table 1 . Phylogenetic relationships of $C$. chromis individuals based on the mitochondrial control region resulted in two major clades that were recovered both by the neighbour-joining and maximum-parsimony methods, but with low bootstrap support (less than 50\%) (Fig. 3). In addition, samples did not partition according to geographical regions (i.e. there were no fixed differences between regions). Enforced geographically partitioned topologies were found to be significantly worse than the topology presented in Fig. 3 (Shimodaira-Hasegawa test, $P<0.001$ ).

\section{Genetic divergence and molecular clock calibration}

Genetic divergences between species are given in Table 2 for each separate locus and can be visualized in the combined phylogram presented in Fig. 2. As expected mutation rates for the mitochondrial loci were highest for the control region, intermediate for cyt $b$, and slowest for 16S rRNA (e.g. McMillan \& Palumbi 1997; Bernardi et al. 2001). The divergence between the pair of geminate species, C. multilineata and C. atrilobata, was higher than the divergence between the target species, C. chromis and C. limbata, for all molecular markers used. The ratio between the divergence across the Isthmus of Panama (C. atrilobata/C. multilineata) and Atlantic islands/Mediterranean (C. limbata / C. chromis) was 2.52 for the mitochondrial control region, 2.85 for cyt $b, 1.07$ for $16 \mathrm{~S}$ rRNA and 3.33 for the nuclear tropomyosin intron. We compared maximum-likelihood topologies with or without enforcing a molecular clock using a Shimodaira-Hasegawa test (Shimodaira \& Hasegawa 1999) for D-loop, cyt $b, 16 \mathrm{~S}$ and tropomyosin. Topologies were not significantly different (difference in $\log L=0 ; P=1$ for all markers). Therefore we assumed homogeneity of rates of molecular evolution for these markers.

The rise of the Isthmus of Panama, which is assumed to be responsible for the split of C. multilineata and C. atrilobata, occurred between 3.1 and 3.5 Ma (Coates \& Obando 1996). This vicariant event has been used in other studies to calibrate mutation rates and estimate mutation rates $(\mu)$ in closely related lineages (Bermingham \& Lessios 1993; Knowlton et al. 1993; Bermingham et al. 1997; Lessios 1998; Donaldson \& Wilson 1999; McCartney et al. 2000).

Using this calibrated clock, the time of divergence between C. chromis and C. limbata ranged from 0.93 to $3.26 \mathrm{Ma}$ depending on the molecular marker used (Table 2).

\section{Population structure}

As mentioned above, mitochondrial control region sequences of $C$. chromis individuals clustered in two major clades. $F_{\mathrm{ST}}$ and AMOva tests were performed with all C. chromis individuals. In order to detect if the implicit phylogenetic signal was artificially producing significant results for these tests, we performed the same analysis on a subset of individuals from only the larger of the two clades. Both procedures gave similar results, indicating that the presence of the clades was not responsible for the significance of the tests. We therefore performed the remainder of the population analysis using all samples.

Comparing to other damselfishes (Fauvelot et al. 2003), all C. chromis populations analysed showed high haplotype diversity values (ranging from 0.792 to 1 , Table 1 ). Population structure of $C$. chromis was first assessed by looking at gene flow between the 18 populations in our study (Table 3). Gene flow between populations was found 
4058 V. S. DOMINGUES ET AL.

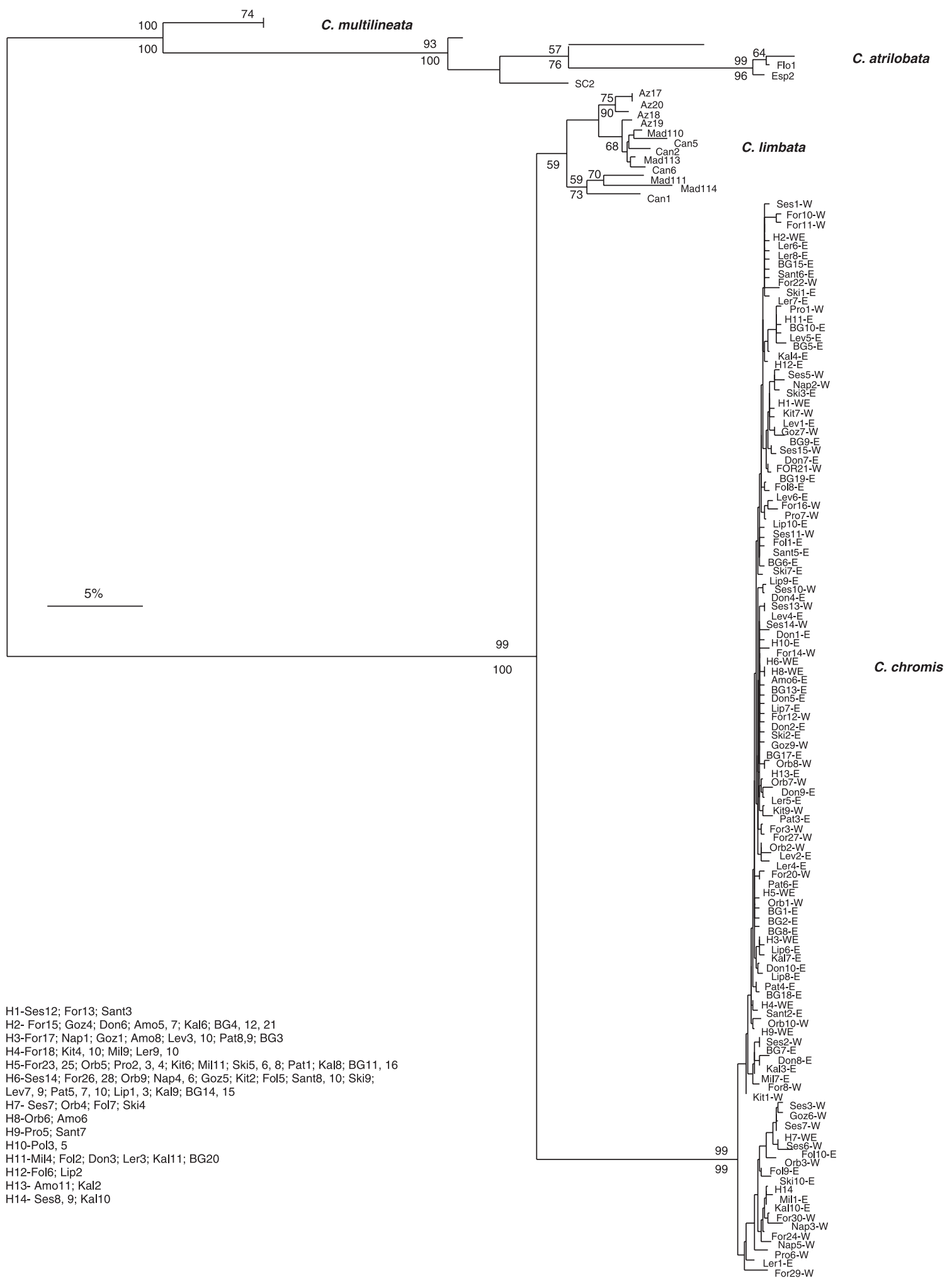

Fig. 3 Phylogenetic relationship within Chromis chromis and its sister species Chromis limbata with Chromis multilineata and Chromis atrilobata used as outgroups. The phylogenetic tree, based on mitochondrial control region (D-loop), was obtained using the neighbour-joining method (with HKY + G model), implemented by the software package PAUP (version 4.0, Swofford 1998). Maximum parsimony resulted in the same topology. Labels are described in Table 1. Additionally individuals belonging to the western or eastern groups are indicated by a $\mathrm{W}$ or $\mathrm{E}$, respectively, after each label (see text). The length of each branch is proportional to the number of nucleotide substitutions. Bootstrap values above $50 \%$ for each node are shown as percentages for neighbour joining and parsimony, above and below the nodes, respectively. 
Table 3 Gene flow among Chromis chromis populations represented by $N m$ (below the diagonal) and $F_{\mathrm{ST}}$ (above the diagonal), calculated from mitochondrial control region sequences using ARLEQUIN version 2.000 (Schneider et al. 2000). Significant $P$ values $(P<0.05)$ are indicated by an asterisk (after Bonferroni correction). Nm values below one migrant per generation are in bold

\begin{tabular}{|c|c|c|c|c|c|c|c|c|c|c|c|c|c|c|c|c|c|c|}
\hline & Ses & For & Orb & $\begin{array}{l}\text { Nap/ } \\
\text { Pro }\end{array}$ & Goz & Kith & Mil & Fol & Sant & Ski & Don & Amo & Lev & Pat & Lip & Ler & Kal & B.G. \\
\hline Ses & & 0.07 & 0.08 & 0.08 & 0.00 & 0.12 & $0.51^{*}$ & $0.53^{*}$ & 0.12 & $0.54^{*}$ & $0.64^{*}$ & $0.59^{*}$ & $0.54^{*}$ & $0.67^{*}$ & $0.55^{*}$ & $0.63^{*}$ & $0.62^{*}$ & $0.35^{*}$ \\
\hline For & 6.64 & & 0.00 & 0.00 & 0.04 & 0.00 & $0.45^{*}$ & $0.49^{*}$ & 0.00 & $0.52^{*}$ & $0.60^{*}$ & $0.58^{*}$ & $0.47^{*}$ & $0.63^{*}$ & $0.48^{*}$ & $0.60^{*}$ & $0.59^{*}$ & $0.25^{*}$ \\
\hline Orb & 5.75 & $\inf$ & & 0.00 & 0.07 & 0.06 & $0.39 *$ & $0.43^{*}$ & 0.00 & $0.48^{*}$ & $0.60^{*}$ & $0.56^{*}$ & $0.43^{*}$ & $0.64^{*}$ & $4^{*}$ & $1^{*}$ & $9^{*}$ & 0.20 \\
\hline Nap/Pro & 5.75 & 303 & inf & & 0.09 & 0.37 & $0.48^{*}$ & $0.51^{*}$ & 0.00 & $0.53^{*}$ & $0.64^{*}$ & $0.62^{*}$ & $0.51^{*}$ & $0.69^{*}$ & $0.52^{*}$ & $0.65^{*}$ & $0.63^{*}$ & $0.28^{*}$ \\
\hline Goz & inf & 10.91 & 7.08 & 4.87 & & 0.11 & 0.56 & $0.59^{*}$ & 0.13 & $0.60^{*}$ & $0.74^{*}$ & 0.71 & $0.59^{*}$ & $0.82^{*}$ & $0.63^{*}$ & 0.75 & 0.73 & $0.36^{*}$ \\
\hline Kith & 3.67 & 94.20 & 7.87 & 13.04 & 4.02 & & 0.57 & $0.62^{*}$ & 0.00 & $0.61^{*}$ & $0.75^{*}$ & 0.75 & $0.60^{*}$ & $0.84^{*}$ & $0.64^{*}$ & $0.78^{*}$ & $0.75^{*}$ & $0.33^{*}$ \\
\hline Mil & $0.48^{*}$ & $0.61^{*}$ & $0.78^{*}$ & $0.55^{*}$ & 0.39 & 0.37 & & 0.01 & 0.53 & 0.15 & 0.30 & 0.26 & 0.00 & 0.37 & 0.00 & 0.32 & 0.27 & 0.05 \\
\hline Fol & $0.44^{*}$ & $0.51^{*}$ & $0.66^{*}$ & $0.46^{*}$ & $0.34^{*}$ & $0.31^{*}$ & 46.32 & & $0.57^{*}$ & 0.28 & $0.47^{*}$ & 0.41 & 0.08 & $0.56^{*}$ & 0.05 & $0.48^{*}$ & $0.44^{*}$ & 0.10 \\
\hline Sant & 3.67 & $\inf$ & 305 & inf & 3.36 & inf & 0.44 & $0.38^{*}$ & & $0.58^{*}$ & $0.72^{*}$ & $0.72 *$ & $0.55^{*}$ & $0.81^{*}$ & $0.59^{*}$ & $0.75^{*}$ & $0.72^{*}$ & 0.28 \\
\hline Ski & $0.43^{*}$ & $0.47^{*}$ & $0.54^{*}$ & $0.44^{*}$ & $0.33^{*}$ & $0.31^{*}$ & 2.82 & 1.31 & $0.36^{*}$ & & 0.01 & 0.03 & 0.16 & 0.15 & 0.22 & 0.10 & 0.00 & $0.29^{*}$ \\
\hline Don & $0.28^{*}$ & $0.34^{*}$ & $0.34^{*}$ & $0.28^{*}$ & $0.17^{*}$ & $0.16^{*}$ & 1.19 & $0.57^{*}$ & $0.19 *$ & 61.43 & & 0.06 & 0.28 & 0.08 & 0.38 & 0.07 & 0.00 & $0.38^{*}$ \\
\hline Amo & $0.35^{*}$ & $0.36^{*}$ & $0.39^{*}$ & $0.31^{*}$ & 0.20 & 0.16 & 1.40 & 0.72 & $0.20^{*}$ & 17.18 & 7.99 & & 0.27 & 0.11 & 0.36 & 0.00 & 0.00 & 0.37 \\
\hline Lev & $0.43^{*}$ & $0.56^{*}$ & $0.67^{*}$ & $0.48^{*}$ & $0.34^{*}$ & $0.33^{*}$ & inf & 5.42 & $0.40^{*}$ & 2.55 & 1.27 & 1.34 & & 0.36 & 0.00 & 0.32 & 0.28 & 0.09 \\
\hline Pat & $0.25^{*}$ & $0.30^{*}$ & $0.28^{*}$ & $0.23^{*}$ & $0.11^{*}$ & $0.10^{*}$ & 0.85 & $0.40^{*}$ & $0.12^{*}$ & 2.75 & 5.85 & 3.84 & 0.88 & & 0.45 & 0.15 & 0.10 & 0.42 \\
\hline Lip & $0.41^{*}$ & $0.53^{*}$ & $0.64^{*}$ & $0.45^{*}$ & $0.30^{*}$ & $0.28^{*}$ & inf & 8.55 & $0.35^{*}$ & 1.78 & 0.83 & 0.89 & inf & 0.60 & & 0.42 & 0.36 & 0.06 \\
\hline Ler & $0.29^{*}$ & $0.33^{*}$ & $0.32^{*}$ & $0.27^{*}$ & 0.16 & $0.14^{*}$ & 1.07 & $0.53^{*}$ & $0.17^{*}$ & 4.61 & 6.90 & inf & 1.07 & 2.87 & 0.69 & & 0.03 & 0.40 \\
\hline $\mathrm{Kal}$ & $0.31^{*}$ & $0.35^{*}$ & $0.35^{*}$ & $0.30^{*}$ & 0.18 & $0.16^{*}$ & 1.37 & $0.64^{*}$ & $0.19^{*}$ & inf & inf & inf & 1.31 & 4.25 & 0.87 & 17.25 & & 0.38 \\
\hline B.G. & $0.93^{*}$ & $1.50^{*}$ & $1.94^{*}$ & $1.29^{*}$ & $1.90^{*}$ & $1.01^{*}$ & 10.08 & 4.27 & 1.28 & $1.23^{*}$ & $0.80^{*}$ & 0.85 & 5.22 & 0.70 & 7.52 & 0.75 & 0.23 & \\
\hline
\end{tabular}

to be remarkably low, with more than half of the $N m$ values below the threshold value of one migrant per generation, 89 out of 153 pairwise comparisons $(58.2 \%)$, and $117(76.5 \%)$ below five migrants per generation (Table 3 ). We detected no significant correlation between $F_{\mathrm{ST}}$ and log-geographical distance in C. chromis populations $\left(r^{2}=0.016, P>0.05\right)$.

A series of AMOVAs with alternative groupings showed that the highest degree of differentiation was found when partitioning populations into two groups (western and eastern), with the boundary between these groups falling between the Greek islands of Kithira and Milos (Table 4, Fig. 1). Gene flow between the Kithira and Milos populations was indeed very low $\left(F_{\mathrm{ST}}=0.57, \mathrm{Nm}=0.37\right)$, but not the lowest observed. Average number of migrants per generation $(\mathrm{Nm})$ within western and eastern groups was 9.63 and 1.28, respectively, while average $N m$ between these two regions was only 0.45 migrant per generation.

\section{Historical demography}

Historical demography was assessed by determining historical population size and growth using the control region sequences of all the $C$. chromis and also partitioning the data in western and eastern groups (Table 5). In all cases, populations were growing at a relatively slow rate (Table 5). Migrations between western and eastern groups were also determined. Migration between these regions was reduced, with a small eastward trend that was statistically significant (49.478 eastward migrants vs. 0.476 westward migrants). A chi-squared goodness-of-fit test
Table 4 Results of hierarchical analysis of molecular variance (AMOVA) of mtDNA control region haplotypes performed in ARLEQUIN (version 2.000; Schneider et al. 2000). Significance ( $p$ ) is defined as the probability of finding a higher among-group variance component and $\phi_{\mathrm{CT}}$ than the observed value. Significant $P$ values $(P<0.05)$ are indicated by an asterisk (after Bonferroni correction). Region labels are described in Table 1 and Fig. 1

\begin{tabular}{lccccc}
\hline $\begin{array}{l}\text { Region } \\
\text { groupings }\end{array}$ & $\phi_{\mathrm{SC}}$ & $\phi_{\mathrm{ST}}$ & $\phi_{\mathrm{CT}}$ & $\begin{array}{l}\text { \% variance } \\
\text { among groups }\end{array}$ & $P$ \\
\hline$(1)(2-8)$ & 0.417 & 0.459 & 0.071 & 7.14 & 0.11347 \\
$(1,2)(3-8)$ & 0.388 & 0.483 & 0.156 & 15.58 & 0.07491 \\
$(1-3)(4-8)$ & 0.284 & 0.521 & 0.331 & 33.11 & $0.00040^{*}$ \\
$(1-4)(5-8)$ & $\mathbf{0 . 2 4 0}$ & $\mathbf{0 . 5 3 3}$ & $\mathbf{0 . 3 8 5}$ & $\mathbf{3 8 . 4 8}$ & $\mathbf{0 . 0 0 0 0 0 ^ { * }}$ \\
$(1-5)(6-8)$ & 0.284 & 0.510 & 0.316 & 31.55 & $0.00000^{*}$ \\
$(1-6)(7-8)$ & 0.379 & 0.464 & 0.138 & 13.76 & 0.03822 \\
$(1-7)(8)$ & 0.435 & 0.377 & -0.103 & -10.33 & 0.94614 \\
$(1)(2-4)(5-8)$ & 0.250 & 0.512 & 0.349 & 34.94 & $0.00000^{*}$ \\
\hline
\end{tabular}

assuming equal rates of migration in both directions rejected this null hypothesis $\left(\chi^{2}=6.4\right.$, d.f. $\left.=1, P<0.05\right)$. In addition, in both western and eastern groups, bimodal mismatch distributions (not shown) and Tajima's $D$ test (west $D=$ $-1.29, P=0.096$; east $D=-1.11, P=0.13$ ) show no significant bottleneck or recent demographic expansion for these groups.

Relative historical population size was determined, allowing us to estimate the coalescence time for C. chromis and its eastern and western groups. Considering a generation time of 3 years (Mapstone \& Wood 1975; Dulcic \& 
Table 5 Demographic parameters of Chromis chromis based on mtDNA control region. Estimates of number of immigrants, $\Theta$ (compound parameter representing the effective population size and mutation rate), $\mathrm{g}$ (growth parameter), and coalescence time for $\mathrm{C}$. chromis based on mitochondrial control region data. Parameters were estimated using Migrate version 2.0 (Beerli 2004) and FLUCTUATE (Kuhner et al. 1998). The standard deviation is presented between parentheses after each estimator

\begin{tabular}{|c|c|c|c|c|c|}
\hline & Immigrants & $\Theta$ (no growth) & $\Theta$ (growth) & $\mathrm{g}$ & $\begin{array}{l}\text { Coalescence } \\
\text { time (Ma) }\end{array}$ \\
\hline C. chromis & & $0.274( \pm 0.010)$ & $0.897( \pm 0.178)$ & $308.026( \pm 45.979)$ & $0.14-0.21$ \\
\hline West & $0.476( \pm 1.428)$ & $0.136( \pm 0.004)$ & $0.541( \pm 0.118)$ & $325.602( \pm 45.127)$ & $0.13-0.20$ \\
\hline East & $49.478( \pm 12.395)$ & $0.151( \pm 0.008)$ & $0.835( \pm 0.130)$ & $485.322( \pm 42.402)$ & $0.09-0.13$ \\
\hline
\end{tabular}

Kraljevic 1995), and estimating $\mu$ for mitochondrial control region as $8.24 \times 10^{-8}-9.30 \times 10^{-8}$, the $C$. chromis population was $1 \%$ of its present size approximately $0.14-0.21 \mathrm{Ma}$ (Table 5). The coalescence times for the western and eastern populations were $0.13-0.20 \mathrm{Ma}$ and $0.09-0.13 \mathrm{Ma}$, respectively (Table 5).

\section{Discussion}

The Mediterranean C. chromis together with its Atlantic sister species C. limbata provide an opportunity to clarify the history and evolution of the northeastern Atlantic/ Mediterranean marine fish fauna. This study also presents an occasion to understand the speciation mode of $C$. chromis.

\section{Evolutionary origin of $\mathrm{C}$. chromis}

In order to estimate the timing of speciation for a particular species, two approaches may be used. The most commonly used approach is to determine the time of divergence between the target species and its sister species. However, the divergence time of two sister species has been shown to most likely be an overestimate of their actual coalescence time (Edwards \& Beerli 2000). When using a molecular clock based on the divergence between the transisthmian geminate species Chromis multilineata and Chromis atrilobata, the divergence time of $C$. chromis, from its sister species C. limbata, was estimated at 0.93-3.26 Ma (Table 2), depending on the molecular marker used. As seen in other systems (Lessios 1998), estimates of divergence time for sister species are different depending on the markers used. Reasons for these differences are discussed elsewhere (Gillespie 1986; Vawter \& Brown 1986; Takahata 1987). A second approach to determine speciation time is to estimate the age of the most recent common ancestor using the time of coalescence for the species. In the case of C. chromis, the time of coalescence based on control region sequences was reached $0.14-0.21$ Ma (Table 5). In all estimates presented here, either using divergence time based on four loci, or coalescence time based on control region, the time of speciation of $C$. chromis was always posterior to the replenishment of the Mediterranean basin, after the MSC, which occurred 5-6 Ma. Our values suggest a Middle to Upper Pliocene or more likely Lower Pleistocene origin of C. chromis. The timing of speciation of C.chromis could be explained by the following scenario: after the desiccation of the Mediterranean during the MSC, it refilled from the Strait of Gibraltar, and was colonized by an Atlantic fauna. By that time, Chromis entered the Mediterranean and evolved there into C. chromis, while the Atlantic lineage diverged into C. limbata. It is important to note that during the Pliocene there was a progressive cooling of the northeastern Atlantic that reached its extreme with the Pleistocene glaciations (Briggs 1996). The waters of the Iberian Peninsula were particularly affected by the polar front located just in front of its western coast during some glacial peaks (Dias et al. 1997). Warm-water species, such as C. chromis, were probably extinct in the northeastern Atlantic during the Pleistocene, and would have been confined to the tropical Atlantic and the Mediterranean where cooling was much less pronounced (Thiede 1978). Additionally, changes that occurred in the current system in the Atlantic Ocean during the glaciations may also have restricted connectivity between the Atlantic and the Mediterranean. Thus, glacial peaks and oceanographic conditions may have provided sufficient isolation between Chromis populations to promote separation of C. chromis and C. limbata. According to this scenario, C. chromis could not have been present in Sesimbra during the Pleistocene glaciations. Thus, this population has probably resulted from a postglacial recolonization of the Atlantic from the Mediterranean. Indeed, our data do not show any sign of C. chromis from Sesimbra being ancestral to the Mediterranean populations.

Our data, however, cannot exclude the possibility of an Atlantic divergence of C. limbata and C. chromis that would have occurred after the MSC, and would later have been followed by an invasion of the Mediterranean by the C. chromis lineage. This scenario would predict a more recent invasion of the Mediterranean, which would result in a stronger signature of colonization within the Mediterranean, possibly with a more recent eastward migration of 
individuals. This hypothesis seems less likely as it requires a rapid colonization of the Mediterranean and an extinction of Atlantic populations of C. chromis over a relatively short time.

\section{Genetic structure}

Several studies have shown restricted gene flow between the Atlantic and the Mediterranean for different marine organisms. However, we found no signs of an AtlanticMediterranean divide for C. chromis. Indeed, high levels of gene flow were found between the Atlantic (Sesimbra) and the Mediterranean, and the percentage of molecular variance among groups when separating the Atlantic from the Mediterranean was only $7.14 \%$ (Table 4 ). Lack of genetic structure between the Atlantic and the Mediterranean has also been reported for the Norway lobster (Stamatis et al. 2004), the wrasse Thalassoma pavo (Costagliola et al. 2004), the chub mackerel Scomber japonicus (Zardoya et al. 2004), and two sparids Pagrus pagrus and Pagellus bogaraveo (Bargelloni et al. 2003).

Within the Mediterranean, population structure and demographic characteristics were evaluated. Eastern and western groups of $C$. chromis were found to have little genetic exchange and there were no signs of an isolation by distance either. Other marine species have been found to partition genetically at the Tunisia-Sicily saddle (Fig. 1), where a land bridge was probably present during the last Pleistocene low sea water level period. In contrast other organisms, including C. chromis, show a genetic break at the Peloponnese (the anchovy Engraulis encrasicolus, Magoulas et al. 1996; the sea bass Dicentrarchus labrax, Bahri-Sfar et al. 2000; the bivalve Cerastoderma glaucum, Nikula \& Väinölä 2003; and the wrasse T. pavo, Costagliola et al. 2004). These genetic breaks are probably linked to the radical climatic and hydrological changes of the Pleistocene that led to partial isolation of Mediterranean fish populations. Besides being limited, gene flow between western and eastern groups was found to be directional and eastbound (Table 5). Furthermore, the eastern group was found to be more recent (coalescent time $0.09-0.13 \mathrm{Ma}$ ) and with a faster growing population $(\mathrm{g}=485.322)$ than the western group (coalescent time $=0.13-0.20 \mathrm{Ma}, \mathrm{g}=308.026$ ). No sudden population expansion or bottlenecks were detected for both western and eastern groups. Coalescent time for the western group was almost identical to the coalescent time for the species $(0.14-0.21 \mathrm{Ma})$. Taken together, these results suggest that $C$. chromis is probably of western origin, and shows a signature of eastward colonization of the Mediterranean basin. Bearing in mind the prohibitive low sea water temperatures in the northeastern Atlantic for warm-water species during the Pleistocene, a western Mediterranean origin of C. chromis is therefore likely, but it is difficult to exclude the possibility of an Atlantic origin of the species.

\section{Maintenance of the present-day situation}

On a much shorter timescale, the presence of a genetic break at the Peloponnese may be explained by some hydrological features of the eastern Mediterranean. Although the Atlantic surface waters are carried eastward by the North African current reaching the Levantine basin, and the surface currents in the Aegean Sea flow towards the Ionian and Levantine basins in summer months, gene flow between western and eastern sides of the Peloponnese are prevented by a quasi-circular anticyclonic feature southwest of the Peloponnese (Malanotte-Rizzoli \& Bergamasco 1989). This intense spot is present throughout the year, but is more pronounced and broader in the spring-summer months, which coincide with $C$. chromis spawing season (June to September, Picciulin et al. 2004). Damselfishes have a bipartite life history with pelagic early life stages and coastalassociated older stages. Like all small coastal fishes $C$. chromis has limited mobility during the adult stage, and dispersal is limited to the larval stage. Pelagic larval duration in C. chromis is relatively short (18-19 days, Raventós \& Macpherson 2001), probably limiting gene flow between populations. The hydrographic scenario described above, together with short pelagic larval duration, may explain the maintenance of the present-day geographical distribution of $C$. chromis genetic diversity.

The history and evolution of the northeastern Atlantic/ Mediterranean marine species is far from being completely understood. Additional sampling and molecular markers would be greatly beneficial to obtain a comprehensive picture. For example, most published works, including this study, tend to have a limited sampling of the southern and easternmost shores of the Mediterranean. Methods, however, are becoming more effective at testing hypotheses. Here we show that combining phylogeographic and coalescent approaches on Mediterranean species provide a powerful means for testing alternative scenarios of Mediterranean colonization history. Chromis chromis was shown to have speciated after the MSC, most likely in the western Mediterranean basin, from an Atlantic ancestor shared with its sister species C. limbata.

\section{Acknowledgements}

We would like to thank several people for providing samples: K. Clifton for C. multilineata, D. Huang for the C. atrilobata from Mexico, R. S. Santos for C. limbata from the Azores and C. A. Brito for C. limbata from the Canaries. We would like to thank the Charles Darwin Research Station, Galapagos, for their help and support. We also thank J. Coll and Estação Maritima do Funchal for field work support. This research was partly funded by a PhD grant SFRH/BD/13069/2003, from the Portuguese Foundation for Science and Technology (V.S.D.), and by the David and Lucille Packard Foundation's PISCO programme (G.B.). V.C.A.'s research unit is funded by FCT through a pluri-annual and programmatic funding schemes (FEDER). 


\section{References}

Allen GR (1991) Damselfishes of the World. Mergus, Melle, Germany. Almada VC, Oliveira RF, Gonçalves EJ et al. (2001) Patterns of diversity of the north-eastern Atlantic blennid fish fauna (Pisces: Blenniidae). Global Ecology and Biogeography, 10, 411-422.

Bahri-Sfar L, Lemaire C, Ben Hassine OK, Bonhomme F (2000) Fragmentation of sea bass populations in the western and eastern Mediterranean as revealed by microsatellites polymorphism. Proceedings of the Royal Society of London. Series B, Biological Sciences, 267, 929-935.

Bargelloni L, Alarcorn JA, Alvarez MC et al. (2003) Discord in the family Sparidae (Teleostei): divergent phylogeographical patterns across the Atlantic-Mediterranean divide. Journal of Evolutionary Biology, 16, 1149-1158.

Beerli P, Felsenstein J (2001) Maximum likelihood estimation of a migration matrix and effective population sizes in n subpopulations by using a coalescent approach. Proceedings of the National Academy of Sciences, USA, 98, 4563-4568.

Beerli P (2004) MIGRATE: documentation and program, part of LAMARK. Version 2.0. Available at http://evolution.gs.washington.edu/ lamarc.html.

Bermingham E, Lessios HA (1993) Rate variation of protein and mitochondrial DNA evolution as revealed by sea urchins separated by the Isthmus of Panama. Proceedings of the National Academy of Sciences, USA, 90, 2734-2738.

Bermingham E, McCafferty SS, Martin AP (1997) Fish biogeography and molecular clocks: Perspectives from the Panamian Isthmus. In: Molecular Systematics of Fishes (eds Kocher TD, Stepien CA), pp. 113-128. Academic Press, San Diego, California.

Bernardi G, Holbrook SJ, Schmitt RJ (2001) Gene flow at three spatial scales in a coral reef fish, the three-spot dascyllus, Dascyllus trimaculatus. Marine Biology, 138, 457-465.

Bohonak AJ (2002) IBD (Isolation by Distance): a program for population genetic analyses of isolation by distance. Journal of Heredity, 93, 153-154.

Borsa P, Blanquer A, Berrebi P (1997) Genetic structure of the flounders Platichthys flesus and P. Stellatus at different geographic scales. Marine Biology, 129, 233-246.

Briggs JC (1974) Marine Zoogeography. McGraw-Hill, New York.

Briggs JC (1996) Global Biogeography, vol. 14. Developments in Paleontology and Stratigraphy. Elsevier, Amsterdam.

Coates AG, Obando JA (1996) The geologic evolution of the Central American Isthmus. In: Evolution and Environment in Tropical America (eds Jackson JBC, Budd AF, Coates AG), pp. 2156. University of Chicago Press, Chicago.

Costagliola D, Robertson DR, Guidetti P et al. (2004) Evolution of coral reef fish Thalassoma pavo spp. (Labridae). 2. Evolution of the eastern Atlantic species. Marine Biology, 144, 377-383.

Dias JA, Rodrigues A, Magalhães F (1997) Evolução da linha de costa em Portugal, desde o último máximo glaciário até à actualidade: síntese dos conhecimentos. Estudos Do Quaternário, 1, 53-66.

Donaldson KA, Wilson RR (1999) Amphi-panamic geminates of snook (Percoidei: Centropomidae) provide a calibration of the divergence rate in the mitochondrial DNA central region of fishes. Molecular Phylogenetics and Evolution, 13, 208-213.

Duggen S, Hoernie K, van den Bogaard P, Rupke L, Morgan JP (2003) Deep roots of the Messinian salinity crisis. Nature, 422, 602-606.

Dulcic J, Kraljevic M (1995) Age, growth, and mortality of damselfish (Chromis chromis L.) in the eastern middle Adriatic. Fisheries Research, 22, 255-264.
Edwards SV, Beerli P (2000) Gene divergence, population divergence, and the variance in coalescence time in phylogeographic studies. Evolution, 54, 1839-1854.

Excoffier L, Smouse PE, Quattro JM (1997) Analysis of molecular variance inferred from metric distances among DNA haplotypes: application to human mitochondrial DNA restriction data. Genetics, 131, 479-491.

Farris JS, Källersjö M, Kluge AG, Bult C (1995) Testing significance of incongruence. Cladistics, 10, 315-319.

Fauvelot C, Bernardi G, Planes S (2003) Reductions in the mitochondrial DNA diversity of coral reef fish provide evidence of population bottlenecks resulting from Holocene sea-level change. Evoluiton, 57 (7), 1571-1583.

Felsenstein J (1985) Confidence limits on phylogenies: an approach using the bootstrap. Evolution, 39, 783-791.

Gillespie JH (1986) Variability of evolutionary rates of DNA. Genetics, 113, 1077-1091.

Golani D (1999) The Gulf of Suez ichthyofauna - assemblage pool for Lessepsian migration into the Mediterranean. Israel Journal of Zoology, 45, 79-90.

Hassan M, Lemaire C, Fauvelot C, Bonhomme F (2002) Seventeen new exon-primed intron-crossing polymerase chain reaction amplifiable introns in fish. Molecular Ecology Notes, 2, 334-340.

Hsü KJ, Montadert L, Bernoulli D et al. (1977) History of the Mediterranean salinity crisis. Nature, 267, 399-403.

Knowlton N, Weight LA, Solorzano LA, Mills DK (1993) Divergence in proteins, mitochondrial DNA, and reproductive compatibility across the Isthmus of Panama. Science, 260, 1629-1632.

Kocher TD, Thomas WK, Meyer A et al. (1989) Dynamics of mitochondrial DNA evolution in animals - amplification and sequencing with conserved primers. Proceedings of the National Academy of Sciences, USA, 86, 6196-6200.

Kotoulas G, Magoulas A, Tsimenides N, Zurros E (1995) Marked mitochondrial differences between Mediterranean and Atlantic populations of the swordfish Xiphias gladius. Molecular Ecology, 4, 473-481.

Krijgsman W, Hilgen FJ, Raffi I, Sierros FJ, Wilson DS (1999) Chronology, causes and progression of the Messinian salinity crisis. Nature, 400, 652-655.

Kuhner MK, Yamato J, Felsenstein J (1998) Maximum likelihood estimation of population growth rates based on the coalescent. Genetics, 149, 429-434.

Lee WJ, Conroy J, Howell WH, Kocher TD (1995) Structure and evolution of teleost mitochondrial control regions. Journal of Molecular Evolution, 41, 54-66.

Lemaire C, Versini J-J, Bonhomme F (2005) Maintenance of genetic differentiation across a transition zone in the sea: discordance between nuclear and cytoplasmic markers. Journal of Evolutionary Biology, 18, 70-80.

Lessios HA (1998) The first stage of speciation as seen in organisms separated by the Isthmus of Panama. In: Endless Forms: Species and Speciation (eds Howard DJ, Berlocher SH), pp. 186201. Oxford University Press, Oxford.

Lythgoe J, Lythgoe G (1971) Fishes of the Sea: The Coastal Waters of the British Isles, Northern Europe and the Mediterranean. Blanford Press, London.

Magoulas A, Tsimenides N, Zouros E (1996) Mitochondrial DNA phylogeny and a reconstruction of the population history of a species: the case of the European anchovy (Eugraulis encrasicolus). Molecular Biology and Evolution, 13, 178-190.

Malanotte-Rizzoli P, Bergamasco A (1989) The circulation of the eastern Mediterranean. Part I. Oceanologica Acta, 12, 335-351. 
Mantel N (1967) The detection of disease clustering and generalized regression approach. Cancer Reaserch, 27, 209-220.

Mapstone GM, Wood EM (1975) The ethology of Abudefduf luridus and Chromis chromis (Pisces, Pomacentridae) form the Azores. Journal of Zoology (London), 175, 179-199.

McCartney MA, Keller G, Lessios HA (2000) Dispersal barriers in tropical oceans and speciation in Atlantic and eastern Pacific sea urchins of the genus Echinometra. Molecular Ecology, 9, 1391-1400.

McMillan WO, Palumbi SR (1997) Rapid rate of control-region evolution in Pacific butterflyfishes (Chaetodontidae). Journal of Molecular Evolution, 45, 473-484.

Narciri M, Lemaire C, Borsa P, Bonhomme F (1999) Genetic study of the Atlantic/Mediterranean transition in sea bass (Dicentrarchus labrax). Journal of Heredity, 90, 591-596.

Nikula R, Väinölä R (2003) Phylogeography of Cerastoderma glaucum (Bivalvia: Cardiidae) across Europe: a major break in the eastern Mediterranean. Marine Biology, 143, 339-350.

Pannacciulli FG, Bishop JDD, Hawkins SJ (1997) Genetic structure of populations of two species of Chthamalus (Crustacea: Cirripedia) in the north-east Atlantic and Mediterranean. Marine Biology, 128, 73-82.

Pérez-Losada M, Guerra A, Sanjuan A (1999) Allozyme differentiation in the cuttlefish Sepia officinalis (Mollusca: Cephalopoda) from the NE Atlantic and Mediterranean. Heredity, 83, 280-289.

Pérez-Losada M, Guerra A, Carvalho GR, Sanjuan A, Shaw PW (2002) Extensive population subdivision of the cuttlefish Sepia officialis (Mollusca: Cephalopoda) around the Iberian Peninsula indicated by microsatellite DNA variation. Heredity, 89, 417424.

Picciulin M, Verginella L, Spoto M, Ferrero EA (2004) Colonial nesting and the importance of the brood size in male parasitic reproduction of the Mediterranean damselfish Chromis chromis (Pisces: Pomacentridae). Environmental Biology of Fishes, 70, 2330.

Posada D, Crandall KA (1998) modeltest: testing the model of DNA substitution. Bioinformatics, 14, 817-818.

Pujolar JM, Roldán MI, Pla C (2002) A genetic assessment of the population structure of swordfish (Xiphias gladius) in the Mediterranean sea. Journal of Experimental Marine Biology and Ecology, 276, 19-29.

Quenouille B, Bermingham E, Planes S (2004) Molecular systematics of the damselfhises (Teleostei: Pomacentridae): Bayesian phylogenetic analyses of mitochondrial and nuclear DNA sequences. Molecular Phylogenetics and Evolution, 31, 66-88.

Quesada H, Beynon CM, Skibinski DOF (1995) A mitochondrial DNA discontinuity in the mussel Mytilus galloprovincialis Lmk: Pleistocene vicariance biogeography and secondary intergradation. Molecular Biology and Evolution, 12, 521-524.

Raventós N, Macpherson E (2001) Planktonic larval duration and settlement marks on the otoliths of Mediterranean littoral fishes. Marine Biology, 138, 1115-1120.

Rice (1989) Analyzing tables of statistical tests. Evolution, 43, 223225.

Riedl R (1983) Fauna und Flora des Mittelmeeres. P. Parey, Hamburg. Rogers AR (1995) Genetic evidence for a Pleistocene population explosion. Evolution, 49, 608-615.
Rogers AR, Harpending H (1992) Population growth makes waves in the distribution pf pairwise genetic differences. Molecular Biology and Evolution, 93, 552-569.

Rozas J, Sánchez-Del Barrio JC, Messeguer X, Rozas R (2003) DNASP, DNA polymorphism analyses by the coalescent and other methods. Bioinformatics, 19, 2496-2497.

Sambrook J, Fritsch EF, Maniatis T (1989) Molecular Cloning: A Laboratory Manual, 2nd edn. Cold Spring Harbor Laboratory Press, Cold Spring Harbor, New York.

Schneider S, Roessli D, Excoffier L (2000) ARLEQUIN, Version 2.000: A software for population genetics data analysis. Genetics and Biometry Laboratory, Department of Anthropology, University of Geneva, Switzerland.

Shimodaira H, Hasegawa M (1999) Multiple comparisons of log-likelihoods with applications to phylogenetic inference. Molecular Biology and Evolution, 16, 1114-1116.

Stamatis C, Trianfylidis A, Moutou KA, Mamuris Z (2004) Mitochondrial DNA variation in northeast Atlantic and Mediterranean populations of Norway lobster, Nephrops norvegicus. Molecular Ecology, 13, 1377-1390.

Stefanni S, Thorley JS (2003) Mitochondrial DNA phylogeography reveals the existence of an evolutionary significat unit of the sand goby Pomatoschistus minutus in the Adriatic (eastern Mediterranean). Molecular Phylogenetics and Evolution, 28, 601-609.

Swofford DL (1998) PAUP: Phylogenetic Analysis Using Parsimony (and Other Methods). Sinauer Associates, Sunderland, Massachusetts.

Tajima F (1989) The effect of change in population size on DNA polymorphism. Genetics, 123, 597-601.

Takahata N (1987) On the overdispersed molecular clock. Genetics, 116, 169-179.

Tang KL (2001) Phylogenetics relationships among damselfishes (Teleostei: Pomacentridae) as determined by mitochondrial DNA data. Copeia, 3, 591-601.

Thiede J (1978) A glacial Mediterranean. Nature, 276, 680-683.

Vawter L, Brown WM (1986) Nuclear and mitochondrial DNA comparisons reveal extreme rate variation in the molecular clock. Science, 234 (4773), 194-196.

Wares JP, Cunningham CW (2001) Phylogeography and historical ecology of the north Atlantic intertidal. Evolution, 55, 2455-2469.

Wood EM (1977) A review of damselfishes (Pisces: Pomacentridae) of the genus Chromis from the central and eastern Atlantic and the Mediterranean. Journal of Fish Biology, 10, 331-345.

Zardoya R, Castilho R, Grande C et al. (2004) Differential population structuring of two closely related fish species, the mackerel (Scomber scombrus) and the chub mackerel (Scomber japonicus), in the Mediterranean Sea. Molecular Ecology, 13, 1785-1798.

Vera Domingues is a PhD student working on the phylogeography of coastal fishes from the eastern Atlantic and the Mediterranean. Giuseppe Bucciarelli is a Mediterranean sailor who works on molecular ecology when the sea is too rough. Vitor Almada is interested in phylogeography of North Atlantic fishes and Iberian freshwater fishes, as well as in behavioural phylogeography. Giacomo Bernardi is interested in ecology, evolution, and speciation of fishes. 